one year's plankton cycle. He found none present during a spring diatom bloom and significant amounts $(0.5-1.5 \mathrm{mgm} . / 1$.) only towards the end of a July dinoflagellate bloom. These amounts were an order of magnitude less than those found in bacteria-free pure cultures of the same organism. He concludes that the material is being utilized almost as fast as it is released : the small quantities present may even be more indicative of rapid utilization than of small production. I cannot wholly agree with his concluding sentence: "Elucidation of the relationships between dinoflagellates and marine bacteria is primarily a task for pure culture techniques in the laboratory" [italic mine]. Doubtless tho laboratory approach is likely to be more immediately rewarding in the present state of knowledge (or lack of knowledge) concerning these organisms, but if anything seems certain about them it is that it would be most unsafe to extrapolate from culture conditions to those existing in Nature without concomitant planned field-work, which should surely be regarded as a primary part of such studies.

The collections of fish eggs and larvæ made by Dr. Riley were studied by Sarah W. Richards in continua. tion of earlier work by Wheatland. The majority of the twenty-two species proved to be summer spawners. In winter no eggs were taken, and larvæ of only one species, Ammodytes americanis, occurred in abundance. Fluctuations in annual totals were caused mainly by the most abundant species, particularly the anchovy, Anchoa mitchilli mitchilli. Only six other species were recorded in large numbers. A greater abundance and variety of species spawned in the western part of the Sound than in the central and eastern portions throughout the year. It appeared that for summer spawners large larvæ from largo eggs did not have an advantage over small larvæ from small eggs since the latter hatched at a time of greater food supply.

$R$. Wade Covill presents a detailed study of the stomach contents of 200 larval and post-larval sand-eels, Ammodytes americanus, 3.2-23.1 mm. long.
Comparison with data from elsewhere showed fewer empty stomachs among the Long Island Sound material ; evidently the Sound provides good feeding for the young of this species. Copepods and their nauplii were the most important food organisms, but phytoplankton was also an important food, especially for the younger and smaller larvæ. It is shown that the larvæ must ingest a considerably greater quantity of food a day than can be deduced from direct examination of stomach contents for growth to continue.

Finally, the editors offer first-class advice and instruction regarding the production of the figures with which papers of this kind should be illustrated. No marine biologist can cavil at anything they have to say, for all the advice is excellent.

Is it not a little unjust to expect marine biologists to be good draughtsmon as well as possessing the wide range of professional knowledge and other semispecialist skills that they must strivo to attain in order to do their job well ? Many who are not so gifted are no wit inferior as scientists to those gifted with a natural facility for drawing. The number of research workers who can hope for the collaboration of a good illustrator is very limited, at least in Great Britain. Too much insistence upon a high standard of graphic presentation can thus lead to suppression of valuable results.

Another point which this, in itself unexceptionable, set of instructions impels one to raise is the need in marine biological papers for less size reduction of figures and more reference lines on graphs (which most editors seem to abhor). Such work often involves voluminous raw data, which for economic and other reasons are nowadays rarely published in full. Graphs from which the values really can be read off are therefore almost the last line of defence against destructive critics who make much of possible alternative arrays of the data, which on close examina. tion are almost always found to be inferior to those selected by the individual who did the work.

T. JOHN HART

\title{
ARTHUR D. LITTLE RESEARCH INSTITUTE
}

$\mathrm{T}$ HE annual report for 1959 of the Arthur D. Little Research Institute, which includes a list of thirty-six publications, nineteen during 1959, records a considerable increase in the scale and scope of the Institute's activities during this its third year of operation, though, as Dr. F. N. Woodward, its director, observed in a paper on sponsored research in Chemistry and Industry for January 9, 1960, not more than $£ 300,000$ was collcctively covered by the three contract research institutes in Great Britain and the research associations of the Department of Scientific and Industrial Research for sponsored research in 1958 (pp. 39. Inveresk, Midlothian : Arthur D. Little Research Institute, 1960).

An investigation aimed at the preparation of polymers from derivatives of glucose was initiated under a four-year grant from the United States Department of Agriculture, and a study of the bulk properties of polymers is being jointly sponsored by British and American companics. A study of aluminium chemistry is being undertaken on behalf of the Atomic Enorgy Authority, and the chemistry and polymer- ization of ethylene sulphide are being investigated for a European sponsor.

The work on the chemistry of sodium sucrates continued and has opened a new route for the preparation of a wide range of sucrose derivatives of potential value, including the sucrose fatty esters, although the problem of removing 'bound' ammonia from sucrates prepared in liquid ammonia has not been completely solved. In the work on the mechanism and kinetics of the formation of isotactic polymers, a new flow apparatus was built and the continuous-flow technique adopted to overcome the difficulty of preparing a reproducible Zicgler catalyst surface, and to afford some insight into the problem of making the polymer production process continuous. An improved model of the viscodensitometer was built and calibrated.

Work in tho corrosion field was particularly fruitful, and 450 organic compounds were tested for inhibitory power using the rapid methods described in the previous report. Although the results did not establish any clear-cut correlation between chemical 
constitution and inhibitory power, they should assist the selection of compounds likely to be effective as inhibitors. Electrochemical methods of studying inhibition have also given interesting results, and the technique of studying inhibition in a flow apparatus with a controlled atmosphere has been considerably improved. Studies of the chemical modification of wood have been extended to include modification of blocks of sapwood specimens and of veneers with the view of assessing improved dimensional stability, and methods have been worked out for the routine evaluation of changes in the physical properties of veneer and whole-wood resulting from chemical modification, and a rapid screening technique for evaluating rot resistance properties of sawdust samples. Infra-red spectroscopy proved to be a particularly valuable method for examining comminuted wood samples.

\title{
POLYPEPTIDES OF THE HUMAN PITUITARY WITH DIRECT ACTION ON METABOLISM
}

\author{
BY DR. J. BORNSTEIN and DEIRDRE HYDE \\ Diabetic and Metabolic Unit, Alfred Hospital, Melbourne
}

$\mathrm{T}$ HE observation by Baird and Bornstein ${ }^{1}$, that residues of plasma following an acid solvent extract contained a fraction capable of inhibiting the uptake of glucose by rat diaphragm, led to the investigation of the human pituitary as a possible source of this material.

Acetone-dried pituitaries are extracted with a mixture consisting of ethanol, 4 vol.; $n$-butanol, 0.4 vol.; toluene, 0.4 vol.; and water, 1.0 vol.; hydrochloric acid to $p \mathbf{H} 1 \cdot 5$ for $5 \mathrm{hr}$. The supernatant is discarded, and the wet residue incubated for $4 \mathrm{hr}$. at $37^{\circ} \mathrm{C}$. and then vacuum dried to remove all traces of solvents. The dry cake is pulverized and extracted with $0.1 M$ acetic acid. The extract is then ultrafiltered through 'Cellophane' at $40 \mathrm{lb}$. per square inch and the ultrafiltrate either freeze dried or precipitated with 15 volumes of absolute ethanol (dried over calcium oxide). The activity of this fraction (P.U.F.) is shown in Table 1.

The crude ultrafiltrate was added at a concentration of the equivalent of 1 gland $/ \mathrm{ml}$. of buffer.

The ultrafiltrate is then chromatographed on a column of 'Zeokarb $225 H$ ' or ' $I R C 120 H$ ', the column being developed with water, $0.1 M$ triethylamine acetate buffer $p \mathrm{H} 6$, followed by $0 \cdot 1 M$ triethylamine buffer $p \mathrm{H} 9 \cdot 4$. Three peaks are observed, the first fraction $\left(H P_{1}\right)$ not absorbing on the column, the

Table 1. Effect of Crude Ultrafiltrate on Glucose Uptake BY RAT DIAPHRAGM (2)

\begin{tabular}{|c|c|c|c|c|c|}
\hline \multirow{2}{*}{$\begin{array}{c}\text { No. of } \\
\text { preparations } \\
\text { tested }\end{array}$} & \multirow{2}{*}{$\begin{array}{l}\text { No. of } \\
\text { dia- } \\
\text { phragms }\end{array}$} & \multicolumn{4}{|c|}{ Glucose uptake in mgm./gm./hr. } \\
\hline & & Control & $\begin{array}{c}\text { With } \\
\text { P.U.F. }\end{array}$ & Diff. & $P$ \\
\hline 6 & 36 & $\begin{array}{l}4.54 \\
S . E .\end{array}$ & $\begin{array}{r}3 \cdot 76 \\
\pm 0 \cdot 14\end{array}$ & $\begin{array}{c}0.78 \\
\pm 0.085\end{array}$ & $<0.001$ \\
\hline
\end{tabular}

second $\left(H P_{2}\right)$ being eluted with buffer $p H \quad 6$ and eluting at $p \mathrm{H} 5 \cdot 2-6 \cdot 0$ and the third $(B P)$ at $p \mathrm{H} \mathbf{9 \cdot 4}$. The third peak $(B P)$ has been inert in all systems and no further reference will be made to it. $H P_{1}$ and $H P_{2}$ showed opposite effects on glucose uptake by rat diaphragm, $H P_{1}$ producing acceleration and $H P_{3}$ inhibition (Table 2).

The inhibitory effect of fraction $\mathrm{HP}_{2}$ has also been investigated in the following systems.

(a) The oxidation of $\mathrm{U}-{ }^{14} \mathrm{C}$ glucose by paired liver slices (Table 3).

(b) The incorporation of carbon-14 amino-acids into protein of rat diaphragm both in vitro and following pre-injection of animals.

The diaphragms of rats starved for $18 \mathrm{hr}$. were incubated in the presence of a protein hydrolysate of activity $1 \mu \mathrm{c} . / \mathrm{ml}$., total amino-acids $80 \mu \mathrm{gm} . / \mathrm{ml}$. and insulin $1 \times 10^{-3}$ unit $/ \mathrm{ml}$. No glucose was added. In injection experiments $160 \mu \mathrm{gm} . \mathrm{HP}_{2}$ was given subcutaneously $18 \mathrm{hr}$. before death and $160 \mu \mathrm{gm} . H P_{2}$ intravenously $30 \mathrm{~min}$. before death. Protein was isolated according to the technique of Manchester and Young. The results are shown in Table 4.

(c) Effect on the incorporation of ${ }^{14} \mathrm{C}$-1-acetate into fatty acids and unsaponifiable lipids by liver slices both in vitro and following injection.

Liver slices taken from rats starved for $18 \mathrm{hr}$., paired in the case of in vitro experiments, and pooled in injection experiments, were incubated in the presence of ${ }^{14} \mathrm{C}$ - 1 -acetate $\mathrm{I} \mu \mathrm{c} . / \mathrm{ml}$., acetate concentra. tion $300 \mu \mathrm{gm} . / \mathrm{ml}$., glucose concentration $2 \mathrm{mgm} . / \mathrm{ml}$. Where injection of animals was undertaken it was carried out as under $b$. The fatty acids and unsaponifiable lipids were recovered according to the technique of Hastings et al. ${ }^{5}$. The results are shown in Table 5.

The unsaponifiable lipids from this series show the same trend as in the in vitro studies, but the results are not statistically significant.

Table 2. EFfect of Fractions $H P_{1}$ AND $H P_{2}$ on GLdCOSE Uptake by Rat Diaphragm

\begin{tabular}{|c|c|c|c|c|c|c|c|}
\hline \multirow{2}{*}{ Peak } & \multirow{2}{*}{$\begin{array}{l}\text { No. of prepara- } \\
\text { tions tested. }\end{array}$} & \multirow{2}{*}{$\begin{array}{l}\text { No. of } \\
\text { diaphragms }\end{array}$} & \multirow{2}{*}{$\begin{array}{l}\text { Concentration in } \\
\mu \mathrm{gm} . / \mathrm{ml} .\end{array}$} & \multicolumn{4}{|c|}{$\begin{array}{c}\text { Glucose uptake by rat diaphragm } \\
\text { mgm./gm./hr. }\end{array}$} \\
\hline & & & & Controls & $+H P_{1}$ & Diff. & $p$ \\
\hline$H P_{1}$ & 4 & 18 & S.E. & $\begin{array}{r}4 \cdot 39 \\
\pm 0.26\end{array}$ & $\begin{array}{r}5.46 \\
\pm 0.29\end{array}$ & $\begin{array}{l}+1.07 \\
\pm 0.247\end{array}$ & $<0.01$ \\
\hline$H P_{2}$ & 9 & 66 & S.E. & $\begin{array}{r}4 \cdot 72 \\
\pm 0 \cdot 16\end{array}$ & $\begin{array}{l}+H P_{2} \\
3.32 \\
\pm 0.17\end{array}$ & $\begin{array}{l}-1 \cdot 40 \\
\pm 0.126\end{array}$ & 0.001 \\
\hline
\end{tabular}

